\title{
On the origins of Cyprideis torosa (Jones, 1850) and a short biography of Professor T. R. Jones
}

\author{
Michael R. Frogley ${ }^{\text {* }}$ \& John E. Whittaker ${ }^{2}$ \\ ${ }^{1}$ Department of Geography, University of Sussex, Brighton BN1 9QJ, UK \\ ${ }^{2}$ Department of Palaeontology, The Natural History Museum, London SW7 5BD, UK \\ * Correspondence: m.r.frogley@sussex.ac.uk
}

\begin{abstract}
The original description and taxonomic attribution of Cyprideis torosa (Jones, 1850) is reviewed with reference to the type locality at Grays, Essex, SE England and several of the original specimens are re-illustrated. A short biography of its author, the geologist T. R. Jones, is provided.
\end{abstract}

Keywords: ostracods, Cyprideis torosa, T. R. Jones, Grays

Received 07 September 2015; accepted 12 November 2015

Specimens of ostracods now known as Cyprideis torosa were formally described for the first time in 1850 by the British geologist and palaeontologist Thomas Rupert Jones in his paper 'Description of the Entomostraca of the Pleistocene Beds of Newbury, Copford, Clacton, and Grays'. At that time, the Ostracoda were taxonomically grouped with the branchiopods, cephalocarids and maxillopods within the Entomostraca, though this is now considered an obsolete taxon (Martin \& Davis 2001). Jones had been developing an interest in microfossils for some years, in part encouraged by contemporaries such as William Harris, John Morris, William Parker and William Baird (Robinson 1978) and he would go on to become the foremost authority on the British Entomostraca in the second half of the nineteenth century.

\section{Original description}

In his 1850 paper, Jones described a total of eight ostracod taxa collected from Pleistocene sediments of southern eastern England, five of which were new species (Jones 1850). Amongst the material that had been collected from Grays, a site located near Thurrock in Essex, SE England (Fig. 1), were several noded specimens that Jones regarded as a new species within the genus Candona Baird. His description reads (Jones 1850, p. 27):

Candona torosa, nobis. Length 1/20 inch. Pl. III. fig. 6a, b, c, d, e.

Carapace oblong, varying in length according to age. Valves convex; bearing a marginal ridge at the anterior extremity; bounded anteriorly and posteriorly; straight on the ventral and more or less arched on the dorsal border according to age, especially the right valve, which is smaller than the left and narrower posteriorly. The surface of valves is marked with closely-set pittings, coarse in the older specimens, and is raised in adult specimens into 5-7 tubercles. Young specimens in general have the surface almost even, or marked by a slight transverse sulcus near the centre and just posterior to the lucid spots, which indicate the position of the first-developed tubercle; 3-4 tubercles on the posterior moiety of the valve, and 1-3 smaller anteriorly become apparent afterwards. Occasionally well-developed tubercles are present even in very young specimens; and on the other hand individuals reach their full growth without being marked with more than one anterior tubercle.

The hinge is considerably developed, the hinge-margin of the right valve bearing anterior and posterior sets of 'knurlings', which are received into corresponding furrows on the hingemargin of the opposite valve.

Dorsal aspect irregular acute oval; anterior somewhat hexagonal.

Illustrating the specimens by means of five line drawings (reproduced in Fig. 2a), he noted that this distinctive species was common in the Grays sediments. The species name torosa means 'sturdy' or 'muscular' and no doubt the noded valves alluded to this in Jones' mind's eye. He further remarked that he had also been sent Recent specimens of the same species by the malacologist John Pickering, who had discovered an extant population living in ditches at Gravesend, Kent (Fig. 1). Interestingly, these are smooth (see Fig. 3c). Although Jones provides scant detail in this paper about the reasons for his taxonomic attribution, he was able to provide much more explanation in his later monograph (Jones 1857).

Jones did not formally identify a type specimen, so when Kilenyi \& Whittaker came to photograph his original material for inclusion in the Stereo-Atlas of Ostracod Shells (Kilenyi \& Whittaker 1974), they designated a lectotype (Fig. 3a herein). The specimen was chosen by careful comparison with the illustrations accompanying both the original description and those in the later monograph (Jones 1850, 1857); several paralectotypes were also designated (Fig. 3b and d). One of John Pickering's specimens, figured by Kilenyi \& Whittaker (1974), is also reproduced here (Fig. 3c).

\section{7 monograph}

In November 1856, Jones produced A Monograph of the Tertiary Entomostraca of England, a substantial piece of work that was subsequently issued in February 1857 by the Palaeontographical Society. The monograph detailed 58 species of ostracod (30 of which were new) occurring in deposits spanning what we would now recognize as the entire Cenozoic (Jones 1857). There is evidence that Jones had been struggling with the systematics of 


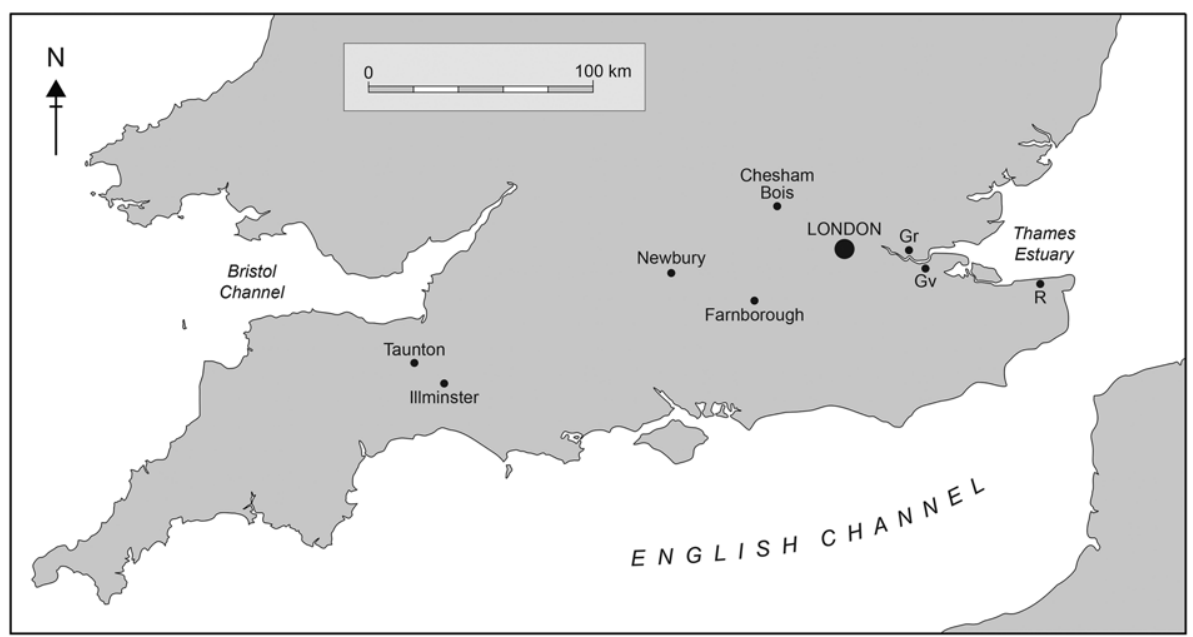

Fig. 1. Map showing main locations referred to in the text, including the type locality of Grays, Essex. Gr, Grays; Gv, Gravesend; R, Reculver. some taxa right up to publication and, in particular, Candona torosa. Having only fossil valves and a few dried specimens to work with, Jones acknowledges that he lacked sufficient modern examples with soft parts to facilitate a full diagnosis. Indeed, on the basis of the anatomical detail that he was able to determine, he cautiously posits (in a note added whilst in press) that these specimens would probably come to be regarded as 'a fresh or brackish water Cythere' (Jones 1857, p. 9). However, pending the availability of living specimens to confirm this hypothesis, and for the purposes of the monograph, he instead provisionally erected Cyprideis as a new sub-genus, based on hinge and carapace morphologies.

The formal description of Cyprideis torosa provided by Jones (1857) repeats his original description of Candona torosa (from Jones 1850) almost verbatim, although provides some limited additional detail (p. 21): 'Lucid spots small, four, arranged in a single transverse, or vertical, row immediately behind the chief, or anterior, tubercle (System C). Dorsal aspect irregular-acute-oval; anterior, somewhat hexagonal.'

On the basis of the accompanying illustrations (reproduced in Fig. 2b), the specimens that Jones was referring to appear to be the same fossil valves from Grays that he originally described in 1850 . In addition, he notes that abundant examples of the same species were recovered from 'deposits of similar age' from two sites near Reculver in Kent (Jones 1857, p. 21) (Fig. 1). Provided by his colleagues Joseph Prestwich FRS (a long-standing friend, later to become Sir Joseph Prestwich) and John Brown (an amateur geologist from Stanway, Essex), Jones comments that these specimens were somewhat smoother than the strongly 'tubercled' forms recovered from Grays. He also refers again to the specimens recovered by John Pickering from populations living in an occasionally tidal ditch at Gravesend (Fig. 1) and notes that they had been found 'in great numbers, attached to the cases of Caddisworms' (Jones 1857, p. 22).

It is beyond the scope of this paper to discuss further the fact that both noded and smooth populations exist in Cyprideis torosa; suffice to say that Jones evidently considered them to belong to a single species. Subsequently, separate names were given to the two forms by other authors, the complex synonymy that ensued being adequately listed by Kilenyi \& Whittaker (1974). The implications of noding, on the other hand, in terms of both ecology and biology, are discussed elsewhere in this special issue of the Journal of Micropalaeontology.

\section{Type locality}

The noded specimens of Cyprideis torosa described by Jones (1850) were collected from sandy interglacial deposits exposed in brick pits at Grays, Essex, in SE England (Fig. 1). In addition to C. torosa, the sediments also contained valves of Ilyocypris gibba a

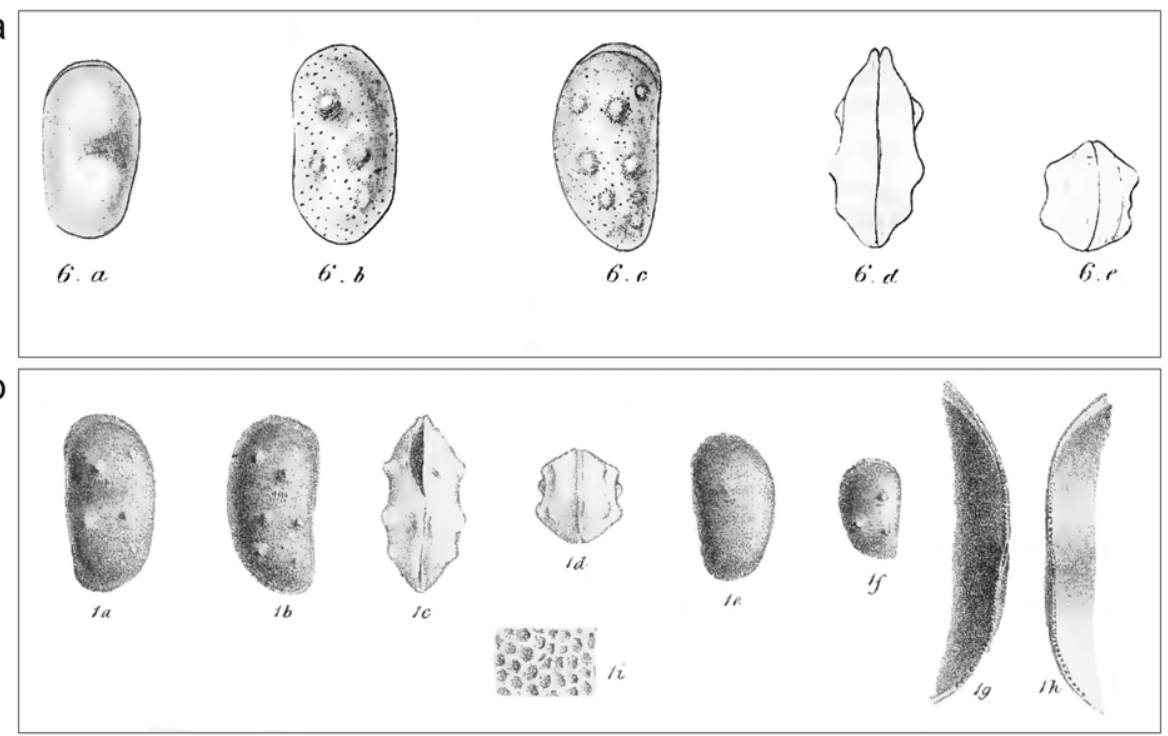

Fig. 2. (a) Reproduction of part of Plate III from 'Description of the Entomostraca of the Pleistocene Beds of Newbury, Copford, Clacton, and Grays' (Jones 1850), illustrated by James De Carle Sowerby. Original caption: 'Fig. 6. Candona torosa +16 : $a$, left valve, young; $b$, left valve, adult; $c$, right valve, adult; $d$, dorsal profile of both valves, adult; $e$, anterior profile of both valves, adult'. (b) Reproduction of part of Plate II from $A$ Monograph of the Tertiary Entomostraca of England (Jones 1857), illustrated by George West. Original caption: 'Cyprideis torosa, p. 21. $a$. Left valve, outside, $\times 25$. $b$. Right valve, outside, $\times 25$. c. Perfect, dorsal aspect, $\times 25$. $d$. Perfect, posterior aspect, $\times 25$. $e$. Left valve, outside, $\times 25 . f$. Right valve, outside, $\times 25 . g$. Right valve, hinge-line, $\times 50 . h$. Left valve, hinge-line, $\times 50$. $i$. Part of surface, $\times 150$ '. Illustrations $a-d$ are further designated as 'old'; all are from the type locality at Grays. 


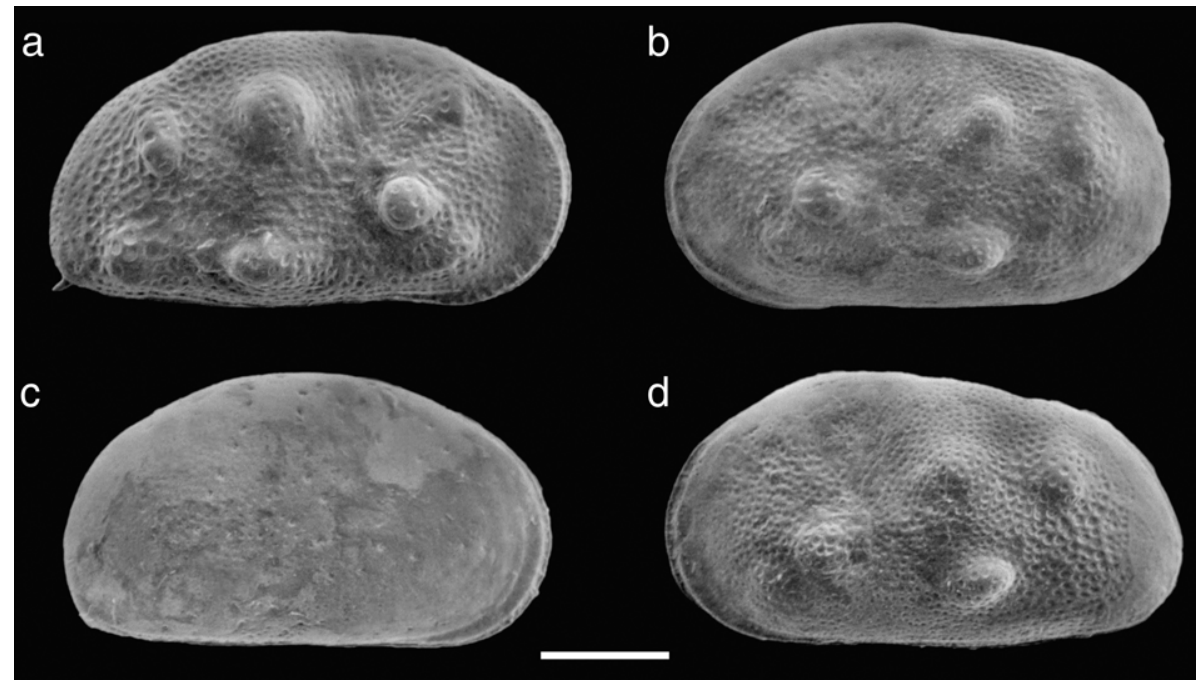

Fig. 3. Scanning electron microscope images of Cyprideis torosa (from Jones original material, held by the Natural History Museum, London).

Figure reproduced from photographic negatives originally taken by Kilenyi \& Whittaker (1974). Scale bar $=250 \mu \mathrm{m}$. (a) Lectotype, specimen no. IO 6002 (RV, male, noded, $1010 \mu \mathrm{m}$ long, slide I 64669) from type locality. Likely to be the specimen figured by Jones (1850, pl. III, fig. 6c; 1857, pl. II, fig. 1b). (b) Paralectotype, specimen IO 6003 (LV, female, noded, $950 \mu \mathrm{m}$ long, slide I 6466-9) from type locality. Likely to be the specimen figured by Jones (1850, pl. III, fig. 6b). (c) Specimen no. IO 6004 (RV, female, smooth, $950 \mu \mathrm{m}$ long, slide no. 50.42) from Gravesend, Kent (Mr Pickering). (d) Paralectotype, specimen no. IN 41844 (LV, male, noded, slightly damaged, $1010 \mu \mathrm{m}$ long) from type locality. Likely to be the specimen figured by Jones (1857, pl. II, fig. 1a).

Ramdohr, Candona candida (Müller), Herpetocypris reptans (Baird) and Scottia tumida (Jones); only the last-named is currently regarded as useful from a biostratigraphical perspective, as it is not known from sediments younger than marine isotope stage (MIS) 9 (Whittaker \& Horne 2009). Interestingly, the Grays locality also yielded valves of what Jones (1850) originally designated as Cythere trigonalis var. laevis, later revised to Potamocypris trigonalis var. laevis (Jones \& Sherborn 1889). As Griffiths (1995) notes, it is not currently possible to identify conclusively this species from Jones' original illustrations and its attribution is therefore uncertain.

From a stratigraphical viewpoint, the deposits at Grays were originally regarded as being of Ipswichian/last interglacial age (Hinton \& Kennard 1900), broadly equivalent with MIS 5e, but they are now ascribed a MIS 9 age on the basis of terrace stratigraphy (Bridgland 1994), mammalian biostratigraphy (Schreve 2001; Schreve et al. 2002) and aminostratigraphy (Penkman et al. 2011, 2013). Grays is situated on the old course of the River Thames. The sediments are fully temperate, probably from the early part of the interglacial (informally known as the 'Purfleet interglacial'; Whittaker \& Horne 2009) and about 330000 years old. They have yielded very rich faunas, especially of vertebrates and molluscs, the 1850s and 1860s being the heyday for collecting. The old brick pits were quarried out by the early 1900s and backfilled; no sections survive.

\section{Thomas Rupert Jones (1819-1911): a brief biography}

The name T. R. Jones is synonymous with an enormous body of taxonomic work in the micropalaeontological and geological literature; indeed, there can be few ostracod or foraminiferal workers who have not encountered his name at some point. Author or co-author of well over 150 academic papers during his lifetime, Jones was notable for his generosity in acknowledging others who provided material or advice, often crediting collectors and colleagues with co-authorships (Robinson 1978). Whilst Jones is perhaps best known for his work on the Entomostraca, including what was probably the first serious attempt to use ostracods as biostratigraphical tools (Horne 2004), his extensive work on foraminifera is no less impressive.

Born in the Cheapside area of London on 1 October 1819 (within the sound of Bow Bells, making him a cockney), Thomas Rupert
Jones soon moved with his family to Taunton in Somerset (Fig. 1), where his father ran a textile business (Woodward 1912). His early interest in geology was stimulated whilst being schooled at Ilminster, where it is generally believed that the fossiliferous Lias deposits of the Jurassic, abundantly exposed in the surrounding area, captured the young Jones' imagination (Woodward 1912). On leaving school, he was apprenticed as a medical assistant, first to a local surgeon in Taunton and subsequently to Dr Joseph Bunny in Newbury, a man known to have had considerable interests in natural history and geology.

In 1844, aged 25, Jones moved back to London where he took up work as a medical assistant. His real passion lay increasingly in the field of micropalaeontology, however, and it is thought that introductions from Dr Bunny probably helped him to gain access to the flourishing scientific scene of Victorian London. The city at that time was undergoing unprecedented expansion and was well on the way to becoming the world's largest (White 2007). Industrialscale engineering infrastructure was the order of the day: road networks were being extended into the broader metropolitan areas, new bridges were being built across the River Thames and, by 1843 , the first of many tunnels beneath it had been completed. Perhaps the most significant transformation of the urban landscape, however, was due to the arrival of the railways along with their associated bridges, sidings, cuttings and stations. All this upheaval meant that geological sections were increasingly being uncovered, providing ample material to fuel scholarly investigation (Robinson 1978). Jones rapidly became a regular contributor at meetings of learned societies and organizations, including the Palaeontographical Society and the Geological Society of London. Introduced to such contemporaries as James Bowerbank, William Parker, John Morris and William Baird (Robinson 1978), Jones was able to learn his craft and to establish what were to become long-standing academic connections. One particularly fruitful introduction was to John Pickering, a conchologist who would provide sediment samples (often sourced at the London docks from returning sailors) that Jones would pick (Cleeveley 1983); indeed, Pickering would continue to provide many samples to Jones throughout his subsequent career, including those from Gravesend in Kent containing recent examples of Cyprideis torosa (Jones, 1850). Another contact was William Harris of Charing, a solicitor's clerk who shared Jones' interest in Chalk fossils, and who would later become his father-in-law. 
In just a few years, Jones became expert on the microfauna of the Cretaceous, submitting the first of several major monographs in 1849 (Jones 1849). His standing in the scientific community was such that, a year later, he was offered a salaried position of Assistant Secretary to the Geological Society of London, a post that he held for the next twelve years. Jones considered editorial work to be a pleasure (Woodward 1911) and he was soon put to work editing the Society's quarterly journal; he also edited new editions of several volumes by Gideon Mantell (following that author's death in 1852), including the well-known Medals of Creation (Mantell 1854) and Wonders of Geology (Mantell \& Jones 1857). In 1858 Jones was appointed a lecturer in geology to the Royal Military College (RMC) at Sandhurst and, on his promotion to Professor four years later, resigned his position at the Geological Society and moved out of London to Farnborough (Fig. 1), in order to live closer to the RMC (Woodward 1911). As Jones' taxonomic reputation grew he was increasingly sent material from around the globe. He published prolifically in all the major journals of the day on specimens ranging throughout the geological column and from localities as diverse as North America, Siberia, the Indian Ocean, the Mediterranean and, especially, South Africa, for which he developed a particular interest (Anon. 1911). Fundamental work on foraminifera featured heavily and, in addition, ostracod marine faunas began to receive considerably more attention than hitherto, thanks in large part to his efforts (Robinson 1978). His extensive work on British Palaeozoic ostracod faunas, for example, established authoritative taxonomic and distributional frameworks that continued to be referenced well into the twentieth century (Siveter \& Lord 2004). He also continued

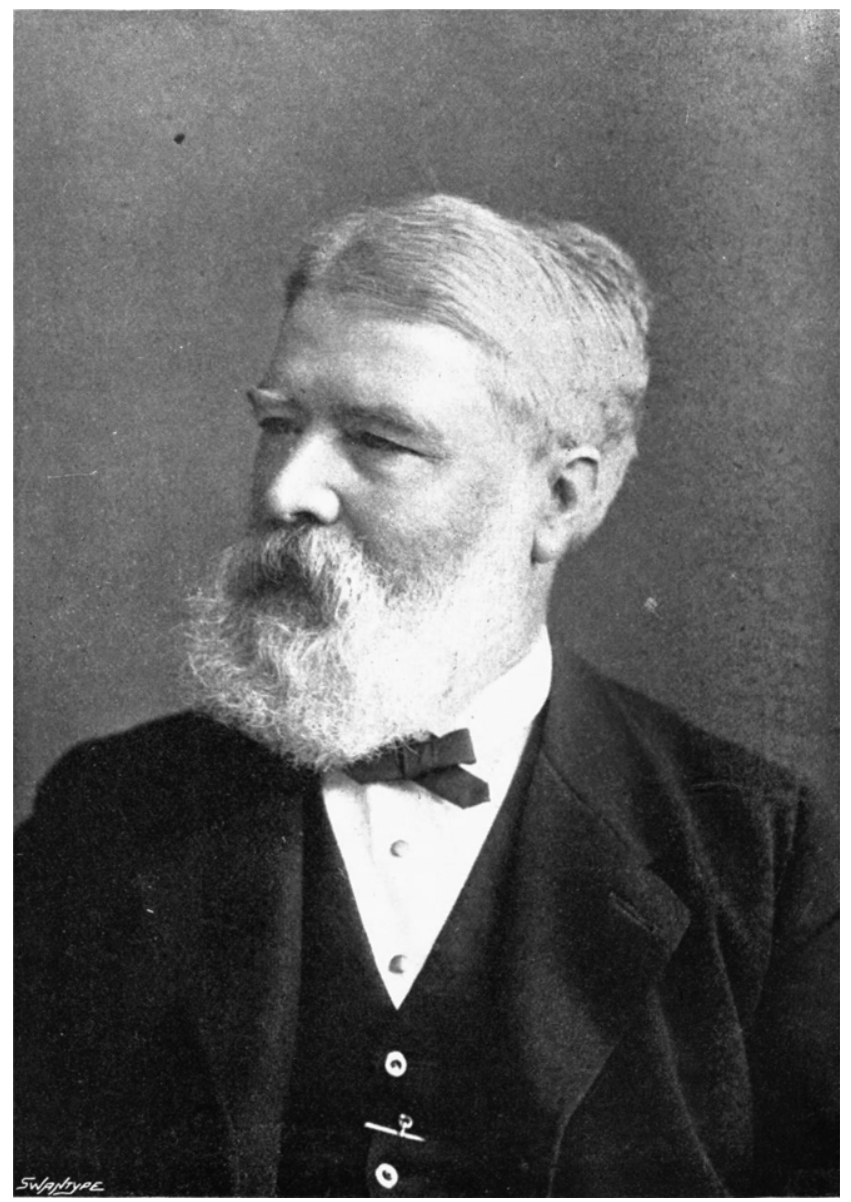

Fig. 4. Photographic portrait of T. R. Jones taken by Southampton photographers Adams \& Stilliard. No date (though Jones is here thought to be about 75 years old). Reproduced from Prestwich (1899, facing p. 376). to revise and edit new editions of major works (such as Dixon's Geology of Sussex [Dixon \& Jones 1878]) and, along with Henry Woodward, was a founding member of the Geological Magazine in 1864. He was elected Fellow of the Royal Society in 1872; amongst his contemporaries would have been such scientific luminaries as Thomas Huxley, Charles Lyell, Joseph Prestwich and Richard Owen (Royal Society 2015). Shortly after his election, Jones was commissioned to edit a manual being prepared for a Royal Societysponsored expedition to the Arctic, for which he also provided chapters on zoology, geology, botany and mineralogy (Jones 1875).

When the army ceased training officer cadets in geological theory, Jones retired from the RMC and, in 1880, moved back to London. He remained scientifically active for the next thirty years, however, continuing to publish widely (often with the help of his assistant, Charles Sherborn), serving on the committees of learned societies (including the Geologists' Association, where he held the post of President for 12 years; Anon. 1911) and receiving numerous awards and accolades, including in 1890 the Lyell Medal of the Geological Society (Fig. 4). In the last few years of his life he retired to the small village of Chesham Bois in Buckinghamshire (Fig. 1), where he died on 13 April 1911, aged 91. Obituaries in Nature (Woodward 1911), the Proceedings of the Geologists' Association (Anon. 1911) and the Proceedings of the Geological Society (Woodward 1912) made clear the significant influence that Jones had had over his lifetime in the fields of micropalaeontology and geology in general. Jones was married twice, fathered ten children (five from each marriage; Woodward 2004) and was buried at St Leonard's Church in Chesham Bois (Siveter \& Lord 2004).

\section{Original material}

Much of Jones' extensive micropalaeontological collection was acquired by the Natural History Museum, London (NHM), including the Cyprideis torosa specimens. His library was sold to the American palaeontologist John Mason Clarke of the New York State Museum of Natural History (Cleeveley 1983).

\section{Acknowledgements and Funding}

We thank the Natural History Museum (NHM), London, for making available Jones' original material for study. We are indebted to Kevin Webb (NHM Image Resources) for providing high-resolution scans of the photographic negatives of the type/illustrated specimens originally featured by Kilenyi \& Whittaker (1974), and also to Richard Hodgkinson (NHM), for making available extensive unpublished biographical notes about T. R. Jones. Eugen Kempf is thanked for application of his precise taxonomic eye. Figure $2 \mathrm{~b}$ is reproduced with permission from the Palaeontographical Society.

Scientific editing by Alan Lord

\section{References}

Anon. 1911. The Annual Report of the Geologists' Association for the Year 1911. Proceedings of the Geologists' Association, 23, 92-99.

Bridgland, D.R. 1994. Quaternary of the Thames. Geological Conservation Review Series, 7. Chapman \& Hall, London.

Cleeveley, R.J. 1983. World Palaeontological Collections. British Museum (Natural History) and Mansell Publishers, London.

Dixon, F. \& Jones, T.R. 1878. The Geology of Sussex; or, The Geology and

Fossils of the Tertiary and Cretaceous Formations of Sussex. 2nd edn. W.J. Smith, Brighton.

Griffiths, H.I. 1995. European Quaternary freshwater Ostracoda: a biostratigraphic and palaeobiogeographic primer. Scopolia, 34, 1-168.

Hinton, M.A.C. \& Kennard, A.S. 1900. Contributions to the Pleistocene geology of the Thames Valley. 1. The Grays-Thurrock area, part 1. Essex Naturalist, 11, 336-370.

Horne, D.J. 2004. Jurassic/Cretaceous of Durlston Bay, Dorset. In: Siveter, D.J. \& Lord, A.R. (eds) In the Footsteps of T.R. Jones: Lower Palaeozoic of Shropshire and the Post-Palaeozoic of Avon, Dorset and Kent. Field Guide for the Thirteenth International Symposium on Ostracoda, Chatham, 1997. British Micropalaeontological Society Field Guide, 10, 46-56.

Jones, T.R. 1849. A monograph of the Entomostraca of the Cretaceous Formation of England. Monograph of the Palaeontographical Society of London, 3, $1-40$. 
Jones, T.R. 1850. Description of the Entomostraca of the Pleistocene Beds of Newbury, Copford, Clacton, and Grays. Annals and Magazine of Natural History (Series 2), 6, 25-28.

Jones, T.R. 1857. A monograph of the Tertiary Entomostraca of England. Monograph of the Palaeontographical Society of London, 9, 1-55.

Jones, T.R. (ed.) 1875. Manual of the Natural History, Geology and Physics of Greenland and the Neighbouring Regions. HMSO, London.

Jones, T.R. \& Sherborn, C.D. 1889. A supplementary monograph of the Tertiary Entomostraca of England. Monograph of the Palaeontographical Society of London, 42, 1-68.

Kilenyi, T.I. \& Whittaker, J.E. 1974. On Cyprideis torosa (Jones). In: SylvesterBradley, P.C. \& Siveter, D.J. (eds) A Stereo-Atlas of Ostracod Shells, 2, 21-32.

Mantell, G.A. 1854. The Medals of Creation; or, First Lessons in Geology and the Study of Organic Remains. 2nd edn. H.G. Bohn, London.

Mantell, G.A. \& Jones, T.R. 1857. The Wonders of Geology. 7th edn. H.G. Bohn, London.

Martin, J.W. \& Davis, G.E. 2001. An Updated Classification of the Recent Crustacea. Natural History Museum of Los Angeles County, Science Series, 39, 1-124.

Penkman, K.E.H., Preece, R.C. et al. 2011. A chronological framework for the British Quaternary based on Bithynia opercula. Nature, 476, 446-449.

Penkman, K.E.H., Preece, R.C. et al. 2013. An aminostratigraphy for the British Quaternary based on Bithynia opercula. Quaternary Science Reviews, 61, 111-134.

Prestwich, G.A. 1899. Life and Letters of Sir Joseph Prestwich. William Blackwood \& Sons, Edinburgh.
Robinson, E. 1978. An outline history of Ostracod studies in Britain. In: Bate, R. H. \& Robinson, E. (eds) A Stratigraphical Index of British Ostracoda. Geological Journal, Special Issue, 8, 7-20.

Royal Society 2015. Fellowship of the Royal Society, https://royalsociety.org/ about-us/fellowship/ [last accessed 18 August 2015]

Schreve, D.C. 2001. Differentiation of the British late Middle Pleistocene interglacials: the evidence from mammalian biostratigraphy. Quaternary Science Reviews, 20, 1693-1705.

Schreve, D.C., Bridgland, D.R. et al. 2002. Sedimentology, palaeontology and archaeology of late Middle Pleistocene River Thames terrace deposits at Purfleet, Essex, UK. Quaternary Science Reviews, 21, 1423-1464.

Siveter, D.J. \& Lord, A.R. (eds) 2004. In the Footsteps of T.R. Jones: Lower Palaeozoic of Shropshire and the Post-Palaeozoic of Avon, Dorset and Kent. In: Field Guide for the Thirteenth International Symposium on Ostracoda. Chatham, 1997. British Micropalaeontological Society Field Guide, 10, 1-65.

White, J. 2007. London in the Nineteenth Century: A Human Awful Wonder of God. Random House, London.

Whittaker, J.E. \& Horne, D.J. 2009. Pleistocene. In: Whittaker, J.E. \& Hart, M.B (eds) Ostracods in British Stratigraphy. The Micropalaeontological Society, Special Publications. Geological Society, London, 447-467.

Woodward, A.S. 1912. The anniversary address of the President. Proceedings of the Geological Society, 68, 58-61.

Woodward, H.B. 1911. Thomas Rupert Jones, F.R.S. Nature, 86, 287.

Woodward, H.B. 2004. Jones, Thomas Rupert (1819-1911), rev. R.J. Cleevely. Oxford Dictionary of National Biography, Oxford University Press, http:/ www.oxforddnb.com/view/article/34239 [last accessed 18 August 2015]. 